\title{
Brief Remarks on the Effect of Judgments on International Law
}

\author{
Prof. Yves Daudet"
}

Strictly speaking and also commonly well-understood, the function of the International Court of Justice is to "decide such disputes as are submitted to it" and to give decisions that, according to Article 59 of its Statute, are binding only upon the parties to the dispute. On several occasions, the Court has recalled that its role must be strictly limited to this purpose and, in this respect, it has declined to exercise any law-making power. For example, in the Advisory Opinion on the Legality of the Threat or Use of Nuclear Weapons, the Court said that:

[...] it states the existing law and does not legislate. This is so even if, in stating and applying the law, the Court necessarily has to specify its scope and sometimes note its general trend. ${ }^{1}$

In the case Armed Activities on the Territory of the Congo (Democratic Republic of the Congo v. Uganda), the Court stated that its:

[...] task must be to respond, on the basis of international law, to the particular legal dispute brought before it. As it interprets and applies the law, it will be mindful of context, but its task cannot go beyond that. $^{2}$

If one takes into account the requirement to decide "in accordance with international law", it is clear that there is a concern to actually identify and define the rule of international law applicable within a system that has long been marked by uncertainty and occasionally by a vacuum, with the aim of presenting a coherent system allowing the establishment of an international society under the rule of law. In this respect, I think that out of

* President of the Curatorium of The Hague Academy of International Law.

1 Legality of the Threat or Use of Nuclear Weapons, Advisory Opinion, ICJ Reports 1996, 237.

2 Armed Activities on the Territory of the Congo (Democratic Republic of the Congo v. Uganda), Judgment, ICJ Reports 2005, 190. 
necessity, one could expect that the Court may crucially contribute to fill this vacuum.

One must also take into account that a Permanent International Court of Justice existed for over 90 years, thus a significant number of judgments has been delivered dealing with numerous questions of international law. However, in addition, a vast collection of conventions and regulations has been adopted which has played a vital role in removing the question of vacuum as it was once known. Thus, the question on whether the judge has to fulfil the role of filling the gaps in international law might be far less crucial in the present day.

Regarding the ways in which a judge may intervene, without explicitly considering whether or not he is a law maker at the end of the day, it must be stressed that the judge is an authority acting "under constraint", being subject to requirements of consistency, continuity and legal security so as to guarantee the confidence of States. The rules of precedent and stare decisis do not apply since these have not been transposed into international law. The Court guarantees its continuity in a way which gives States the benefit of what one might call a "principle of foreseeability". This is understood as foreseeability not with respect to the solution that will be given, but with respect to the content and application of the law and therefore a foreseeability of jurisprudence.

The requirement that jurisprudence should be foreseeable is particularly important in this often-uncertain branch of the law, and is particularly necessary in maintaining the confidence of States. For this purpose, the Court has used wording such as, among many others, those in Land and Maritime Boundary between Cameroon and Nigeria:

The real question is whether, in this case, there is cause not to follow the reasoning and conclusions of earlier cases. ${ }^{3}$

Or, in the Aegean Sea Continental Shelf case of 1978, where it held that:

Although under Article 59 of the Statute the decision of the Court has no binding force except between the parties and in respect of that particular case, it is evident that any pronouncement of the Court as to the status of the 1928 Act, whether it were found to be a convention in force or to be no longer in force, may have implications in the relations between States other than Greece and Turkey. ${ }^{4}$

3 Land and Maritime Boundary between Cameroon and Nigeria (Cameroon v. Nigeria: Equatorial Guinea intervening), Judgment, ICJ Reports 1998, 292.

4 Aegean Sea Continental Shelf (Greece v. Turkey), Judgment, ICJ Reports 1978, 17. 
In the 2004 Avena case, the Court was even more clear and forceful, where it went so far as to hold that:

[...] the fact that in this case the Court's ruling has concerned only Mexican nationals cannot be taken to imply that the conclusions reached by it in the present Judgment do not apply to other foreign nationals finding themselves in similar situations in the United States. ${ }^{5}$

Through this continuity, which not only references what has been previously judged, but also projects into a possible future, the Court is, to some extent, constructing the law. Nevertheless, the Court again acts under the constraint that it can only do so through, and in respect of, cases submitted to it, which it cannot control, and within the limits of the dispute that has been submitted. Even if the Court considers, as it did in the recent case of Obligation to Negotiate an Access to the Pacific Ocean, that:

It is for the Court to determine on an objective basis the subject-matter of the dispute, $[\ldots]$ while giving particular attention to the formulation of the dispute chosen by the applicant. ${ }^{6}$

And while it is true that the Court can always raise legal issues proprio mo$t u$, nevertheless, the exercise of this jurisdiction does have limits. These were recalled by Judge Rosalyn Higgins in her opinion in the Land and Maritime Boundary between Cameroon and Nigeria case:

Although the Court always may raise points of law proprio motu, it is in principle for a respondent State to decide what points of jurisdiction and inadmissibility it wishes to advance. If a State is willing to accept the Court's jurisdiction in regard to a matter, it is generally not for the Court - its entitlement to raise point's proprio motu notwithstanding to raise further jurisdictional objections. ${ }^{7}$

One has also to consider the principle of judicial economy. In this respect, in the Jurisdictional Immunities of the State (Germany v. Italy) 2012 judgement, the Court said that:

5 Avena and Other Mexican Nationals (Mexico v. United States of America), Judgment, ICJ Reports 2004 (I), 70.

6 Obligation to Negotiate Access to the Pacific Ocean (Bolivia v. Chile), Preliminary Objections, ICJ Reports 2.15 (II), 602.

7 Land and Maritime Boundary between Cameroon and Nigeria (Cameroon v. Nigeria: Equatorial Guinea intervening), supra note 3, 347. Nevertheless, it must be stressed that Judge Higgins "thinks that an exception to this principle exists where the matter relates to the requirements of Article 38 of the Statute." (ibid.). 
It is, therefore, unnecessary for the Court to consider a number of questions which were discussed at some length by the Parties. [...] That is not to say, of course, that these are unimportant questions, only that they are not ones which fall for decision within the limits of the present case. ${ }^{8}$

Similarly, in the Gabcikovo case it was stated that:

The Court does not find it necessary for the purposes of the present case to enter into a discussion of whether or not Article 34 of the 1978 Convention on succession of States in respect of Treaties reflects the state of customary international law. ${ }^{9}$

Within those limits, the room for manoeuvre may nevertheless be broad, but the resulting responsibility is very heavy for a Court that gives its judgments in the last resort. Some decisions are good illustrations of this responsibility exercised by the Court in a measured and balanced way so that the law has evolved in order to take into account the way in which the world itself has evolved, without sacrificing foreseeability. One example is the Case concerning Navigational and Related Rights (Costa-Rica v. Nicaragua) in 2009, where the Court found with respect to the meaning of the word "commerce" that:

$[\ldots]$ where the parties have used generic terms in a treaty, the parties necessarily having been aware that the meaning of the terms was likely to evolve over time, and where the treaty has been entered into for a very long period or is "of continuing duration", the parties must be presumed, as a general rule, to have intended those terms to have an evolving meaning. ${ }^{10}$

In doing so, the Court took a position that was not unprecedented. Another example of the Court evolving the law without sacrificing foreseeability is the decision in the Pulp Mills case (Argentina v. Uruguay 2010):

The Court considers that the attainment of optimum and rational utilization requires a balance between the Parties' rights and needs to use the river for economic and commercial activities on the one hand, and

8 Jurisdictional Immunities of the State (Germany v. Italy, Greece intervening), Judgment, ICJ Reports 2012, 145.

9 Gabčíkovo-Nagymaros Project (Hungary/Slovakia), Judgment, ICJ Reports 1997, 71.

10 Dispute regarding Navigational and Related Rights (Costa Rica v. Nicaragua), Judgment, ICJ Reports 2009, 243. 
the obligation to protect it from any damage to the environment that may be caused by such activities, on the other. ${ }^{11}$

One may decide for oneself how to view this, believing either that the Court is seeking a compromise in the wording as it often does for obvious reasons (that it cannot officially recognize), or that, in this way, it is facilitating "a gentle evolution" of international law, or both, as appropriate.

Finally, one could consider that there perhaps still remains a kind of ambiguity between the limits arising out of the fact that the res judicata effect is limited to the parties in contentious matters and the indisputable function of the Court as a "law developer" if not a "law maker". Nevertheless, Christian Tams is probably right in saying that this distinction is "too clearcut", when he ponders, quoting Alvarez "where the development of laws ends and when the creation begins". Both of them give evidence of an "external effect" of the Judgments of the Court, added to the "internal effect" (adhering to Hélène Ruiz Fabri's wording for this seminar) which lie in the settlement of the dispute itself that is the major purpose of the Judgement. Of course, this external effect is perfectly clear not only when the Court delivers obiter dicta, which does not happen very often, but also in cases where the Judgments can be regarded as cornerstones of International law because of the huge number of important questions that are raised. Of course the Military and Para-Military Activities judgements in 1984 and 1986 or the Advisory Opinion on the Expenses or Reservations to the Genocide convention, as well as many others, comprise these cornerstones.

In contrast, there is obviously much more freedom and much less constraint in the doctrine. Even the most restrained and cautious professors are always tempted to construct a system and to seek overall consistency. Professors are allowed to reflect upon lex ferenda and to discourse upon what the law should or could be; they can anticipate evolutions and, occasionally, contribute to them; for example, by acting as consultants, the only condition being, of course, that a clear distinction must always be made between this and lex lata. In other words, they must not take their desires for realities, and should make their standpoint clear. Their fields of investigation are without limits other than those that are dictated by reason.

Is it correct to say that, by means of the opinions or declarations that they may append to a Judgment, Judges acting individually (and thus, to a greater or lesser extent, marking their distance from the majority of the Court), are fulfilling a function that is closer to the doctrinal function?

11 Pulp Mills Case (Argentina v. Uruguay), Judgment, ICJ Reports 2010, 74. 
Some opinions are of considerable value. They can sometimes cast doubt upon a judgment. We have all had the experience of being convinced by a judgment and then being made unsure and, in the end, being convinced by a contrary opinion. Speaking only of those who are no longer with us, and of distant times, mention might be made of the opinions of Anzilotti and the general and almost theoretical views that they propounded with regard to the problems that were submitted to the Permanent Court. Those opinions are certainly much more than simple doctrinal opinions, not only because of their relevance, but also because of their legal effects under certain conditions. In that respect, certain opinions have taken on a significance which goes well beyond what was accepted when the system was put in place. We all remember the declaration of Sir Percy Spender following the judgment that was given by his regrettable casting vote in 1966:

It is only through their relationship to the judgment that a judicial character is imparted to individual opinions. ${ }^{12}$

In this regard, I personally do not subscribe to the idea put forward by Judge ad hoc Serge Sur who, in his individual opinion in the order of 2009, Questions Related to the Obligation to Prosecute or Extradite, ${ }^{13}$ considered that an ad hoc Judge, who is a Judge for the occasion, "may even be freer in the general opinions he expresses than a permanent judge, as he is less constrained by the settled jurisprudence and freer to explore alternative paths" 14 .

In other words, the Judges - and ad hoc Judges - are invited to remain Judges and to resist the temptation to convey messages which they were at liberty to do when, for some of them, they were professors in front of their students! If they cross these boundaries, their opinion is no longer something that is attached to a Court decision, but in the end, becomes nothing more than a doctrinal opinion.

To conclude, convergent and divergent characteristics cross and crisscross in a pattern that naturally leads to complementarity between judicial decisions and the teaching of publicists in order to promote the development of International Law and its external effects.

Complementarities are to be found at several levels. I will just mention one, which looks particularly emblematic. It relates to the establishment of

12 South West Africa (Liberia v. South Africa), Judgment, ICJ Reports 1966,, 57, 32.

13 Questions Relating to the Obligation to Prosecute or Extradite (Belgium v. Senegal), Order, ICJ Reports 2009, 139.

14 Ibid., Separate Opinion of ad hoc Judge Sur, 204. 
legal rules. As professors, we have all been faced with questions from our students along the lines of: "Is it a rule of international law?", "Is it an international custom?", "Is jus cogens really the only Rolls Royce in the garage?", etc. In a number of cases, the answers have been marked by a great deal of caution, hesitation and uncertainty. On the other hand, it is clear that the Court's jurisprudence gives firm directions and guidance. The Court states the existence of a custom, without going into further unnecessary detail as to the components of the custom, and the discussion can then take place on a sound footing. The question of jus cogens leads to conclusions along the same lines. It has given rise to impassioned theoretical debate, and the concept has been used by several judicial or para-judicial bodies, but I believe that its existence was not really established until the Court formally referred to it, using the term expressly, even with cautions in the Congo $v$. Rwanda case ${ }^{15}$ (2006) and the Genocide case ${ }^{16}$ (2007), and this has radically changed the way in which it is presented in the teaching of international law.

15 Case Concerning Armed Activities on the Territory of the Congo (New Application 2002) (Democratic Republic of the Congo v. Rwanda), Judgment, ICJ Reports 2006, 6 .

16 Case Concerning Application of the Convention on the Prevention and Punishment of the Crime of Genocide (Bosnia and Herzegovina v. Serbia and Montenegro), Judgment, ICJ Reports 2007, 43. 
